\title{
Coupled nitrification-denitrification measured in situ in a Spartina alterniflora marsh with a ${ }^{15} \mathrm{NH}_{4}{ }^{+}$tracer
}

\author{
M. R. Hamersley ${ }^{1,3, *}$, B. L. Howes ${ }^{2}$ \\ ${ }^{1}$ Department of Biology, Woods Hole Oceanographic Institution, 45 Water St., Woods Hole, Massachusetts 02543, USA \\ ${ }^{2}$ School for Marine Science and Technology, University of Massachusetts, 706 S. Rodney French Blvd., New Bedford, \\ Massachusetts 02744-1221, USA \\ ${ }^{3}$ Present address: Max Planck Institute for Marine Microbiology, Celsiusstrasse 1, 28359 Bremen, Germany
}

\begin{abstract}
Measurements of $\mathrm{N}$ losses by denitrification from saltmarsh sediments have proved difficult because of the importance of plant metabolism and tidal cycles to sediment $\mathrm{N}$ cycling. In vitro approaches often do not measure the dominant coupled nitrification-denitrification pathway and/or alter in situ plant growth and redox conditions. We developed an in situ ${ }^{15} \mathrm{NH}_{4}{ }^{+}$tracer approach to measure coupled nitrification-denitrification fluxes in an undisturbed New England Spartina alterniflora saltmarsh. The tracer was line-injected into sediments underlying natural $S$. alterniflora stands and in similar areas receiving long-term $\mathrm{N}$ amendment (up to 11.2 mol organic $\mathrm{N}$ $\mathrm{m}^{-2} \mathrm{yr}^{-1}$ for 16 to $23 \mathrm{yr}$ ), and ${ }^{15} \mathrm{~N}$ retention and loss routes were followed for 1 to $5 \mathrm{~d}$. Denitrification losses in unfertilized grass stands ranged from 0.4 to $11.9 \mathrm{mmol} \mathrm{N} \mathrm{m}^{-2} \mathrm{~d}^{-1}\left(0.77 \pm 0.18 \mathrm{~mol} \mathrm{~N} \mathrm{~m}^{-2} \mathrm{yr}^{-1}\right)$. Denitrification in unfertilized sediments remained low until late summer, but underwent a ca. 4 -fold increase in August and September, although sediment temperatures and respiration rates were high throughout the summer. Plant $\mathrm{N}$ uptake may limit the availability of $\mathrm{N}$ to support denitrification during the early summer, and denitrification may be released from competition with plant uptake in late summer, when plant growth slows. Denitrification rates in fertilized areas ranged from 22 to $77 \mathrm{mmol}$ $\mathrm{N} \mathrm{m}^{-2} \mathrm{~d}^{-1}\left(10.5 \pm 4.9 \mathrm{~mol} \mathrm{~N} \mathrm{~m}^{-2} \mathrm{yr}^{-1}\right)$, and denitrification was likely controlled by the availability of fertilizer $\mathrm{N}$ rather than by competition with plants, since $\mathrm{N}$ was added in excess of plant demand. Our results emphasize the importance of in situ measurements of denitrification in understanding the dynamics of saltmarsh $\mathrm{N}$ cycling.
\end{abstract}

KEY WORDS: Saltmarsh $\cdot$ Denitrification $\cdot$ Nitrification $\cdot{ }^{15} \mathrm{~N} \cdot$ Spartina alterniflora

\section{INTRODUCTION}

Denitrification, the anaerobic microbial reduction of oxidized inorganic $\mathrm{N}$ to $\mathrm{N}_{2} \mathrm{O}$ or $\mathrm{N}_{2}$, is acknowledged as an important sink in the saltmarsh $\mathrm{N}$ cycle, but quantifying its contribution has proven difficult. With few allochthonous sources of $\mathrm{NO}_{3}{ }^{-}$, denitrification in highly organic vegetated saltmarsh sediments - such as those in Massachusetts - is supported primarily by coupled nitrification-denitrification of remineralized $\mathrm{NH}_{4}{ }^{+}$ (Patrick \& Reddy 1976, White \& Howes 1994a,b, Howes et al. 1996). In vitro methods appropriate for submerged aquatic sediments neglect the effects of growing plants and tidal inundation and exposure. These in situ biological and physical factors create a complex sediment redox structure by oxidizing the rhizosphere and sediment pores, thereby increasing the availability of oxygen to support nitrification and decreasing the diffusion distance between oxic sites of nitrate production by nitrifying bacteria and anoxic sites of nitrate consumption by denitrifiers (Dacey \& Howes 1984, Risgaard-Petersen \& Jensen 1997, Sundby et al. 1998).

A still common in vitro technique, the acetylene block (e.g. Chabrerie et al. 2001, Tobias et al. 2001b, Sundareshwar et al. 2003, Hefting et al. 2004, Wigand 
et al. 2004, Dollhopf et al. 2005), also blocks nitrification, making it inadequate for measuring coupled nitrification-denitrification (Van Raalte \& Patriquin 1979). The acetylene block is also inhibited by the $\mathrm{S}^{2-}$ levels present in many saltmarsh sediments (Sørensen et al. 1987). More recent methods have measured nitrification and denitrification rates through ${ }^{15} \mathrm{~N}$ isotope dilution and recovery of reaction products, but their application has typically been limited to in vitro incubations (Abd Aziz \& Nedwell 1986, DeLaune et al. 1989, Stepanauskas et al. 1996).

In vitro techniques are inadequate to measure saltmarsh denitrification, because they isolate sediments from plant growth, tides, light, sediment hydrology, and redox conditions. Plant $\mathrm{N}$ uptake competes with nitrification for available $\mathrm{NH}_{4}{ }^{+}$(Buresh et al. 1981, DeLaune et al. 1983, Dean \& Biesboer 1985, White \& Howes 1994a), while root oxygen leakage aerates the rhizosphere, promoting coupled nitrification-denitrification (Reddy et al. 1989, Mendelssohn \& McKee 1992, Arth \& Frenzel 2000). Tidal inundation frequency and its control of the sediment oxidation state may also play a role in regulating nitrification-denitrification (Smith \& Patrick 1983). Nevertheless, few measures of denitrification maintain in situ conditions, and most previous approaches to in situ measurements have been flawed. Landscape-level mass balance approaches suffer from coarse spatial and temporal resolution (Valiela \& Teal 1979, Anderson et al. 1997, van Wijnen \& Bakker 2000). Haines et al. (1977) estimated denitrification rates from sediment $\mathrm{N}_{2}$ gas profiles, but their measurements did not consider sediment porosity, nor was it clear how they accounted for diffusion. Kaplan et al. (1979) measured in situ $\mathrm{N}_{2}$ evolution into He headspaces in small bell jars inserted into surficial sediments, but their method involved the removal of aboveground biomass, cutting of roots, alteration of sediment hydrology, and short incubations in dark enclosures. Smith et al. (1983) measured wetland $\mathrm{N}_{2} \mathrm{O}$ fluxes into dark enclosures, and estimated denitrification rates from $\mathrm{N}_{2} / \mathrm{N}_{2} \mathrm{O}$ ratios determined in a swamp forest (Lindau et al. 1988, DeLaune et al. 1989). ${ }^{15} \mathrm{~N}$ tracers have been used in undisturbed vegetated marsh to determine tracer fate and denitrification losses, but not to measure denitrification rates (Buresh et al. 1981, DeLaune et al. 1983). Tobias et al. (2001a) used an in situ ${ }^{15} \mathrm{NO}_{3}{ }^{-}$groundwater tracer, but their method did not measure coupled nitrification-denitrification, and was used in unvegetated sediments.

In the present study, we developed an in situ ${ }^{15} \mathrm{~N}$ tracer approach to measuring coupled nitrificationdenitrification ('denitrification' or $D_{\mathrm{n}}$ ) in undisturbed marsh grass stands. Our approach was modified from the in situ isotope tracer method of White \& Howes (1994a). In a study of long-term saltmarsh $\mathrm{N}$ retention, they injected ${ }^{15} \mathrm{NH}_{4}{ }^{+}$directly into undisturbed sediments. During their first measurement interval (3 d), ${ }^{15} \mathrm{~N}$ loss was rapid, but subsequent loss was slow, since most of the tracer had become fixed into plant biomass pools with low turnover rates (White \& Howes 1994b). However, the pattern and rate of denitrification $\mathrm{N}$ losses during the initial $3 \mathrm{~d}$ after tracer injection remained unclear, as was the seasonal pattern and annual flux through denitrification.

In the present study, we determined the seasonal pattern of short-term (days) inorganic nitrogen loss from saltmarsh grass stands through nitrificationdenitrification reactions by injecting ${ }^{15} \mathrm{NH}_{4}{ }^{+}$in situ into undisturbed saltmarsh sediments, following total ${ }^{15} \mathrm{~N}$ retention through a series of destructively sampled sediment cores, measuring all non-gaseous ${ }^{15} \mathrm{~N}$ loss routes, and determining denitrification rates by mass balance. Although this approach has the potential to overestimate denitrification losses, with careful quantification of all other potential loss routes, we believe any disadvantages of our approach are outweighed by the advantages of studying denitrification in undisturbed grass stands, under natural conditions of plant and tidal activity. We analyzed the seasonal pattern of denitrification so obtained with respect to the availability of $\mathrm{N}$, regulated by remineralization and plant uptake. We also examined denitrification in grass stands receiving long-term fertilization, where $\mathrm{N}$ was not limiting to plant growth and where our denitrification measurements could be compared to mass balance measures.

\section{MATERIALS AND METHODS}

We measured nitrification-denitrification ('denitrification' or $D_{\mathrm{n}}$ ) by injecting ${ }^{15} \mathrm{NH}_{4}{ }^{+}$in situ into undisturbed vegetated saltmarsh sediments and following total ${ }^{15} \mathrm{~N}$ retention over 1 to $5 \mathrm{~d}$ in a series of destructively sampled $6.5 \mathrm{~cm}$ diameter $\times 10 \mathrm{~cm}$ deep sediment cores and their associated aboveground biomass. Our measure of total ${ }^{15} \mathrm{~N}$ retention included dissolved inorganic as well as organic (plant and microbial) fractions. From the decrease in ${ }^{15} \mathrm{~N}$ recovery over time, we calculated a rate constant for all ${ }^{15} \mathrm{~N}$ losses. We identified and measured all non-gaseous ${ }^{15} \mathrm{~N}$ loss routes out of the sampled core volume and associated aboveground biomass, and adjusted the ${ }^{15} \mathrm{~N}$ loss rate constant to calculate a denitrification rate constant (Fig. 1). This rate constant was applied to the in situ $\mathrm{NH}_{4}{ }^{+}$pool to determine the overall rate of coupled nitrification-denitrification. We further compared these in situ measures to measurements in greenhouse lysimeters, where denitrification was the only loss route, and under in vitro conditions without normal plant function or tidal inundation. 


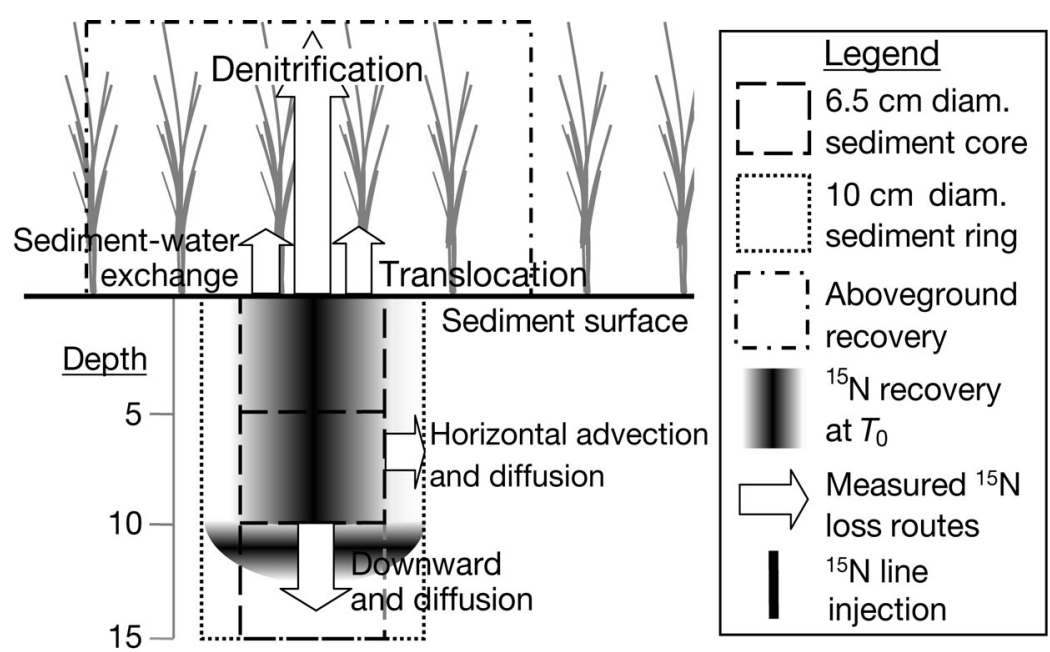

Fig. 1. Measured loss routes of injected ${ }^{15} \mathrm{~N} .{ }^{15} \mathrm{NH}_{4}{ }^{+}$was line-injected to $10 \mathrm{~cm}$ depth in undisturbed vegetated saltmarsh sediments. Total ${ }^{15} \mathrm{~N}$ recovery (during a time course of 1 to $5 \mathrm{~d}$ ) was measured in a series of destructively sampled, $6.5 \mathrm{~cm}$ diameter sediment cores sectioned into $5 \mathrm{~cm}$ intervals $(---) . T_{0}$ recovery of ${ }^{15} \mathrm{~N}$ within the core averaged $93 \%$ (see Table 2; approximate distribution of tracer shown by shading). Changes in ${ }^{15} \mathrm{~N}$ recovery in the 10 to $15 \mathrm{~cm}$ depth interval (no denitrification losses; White \& Howes 1994a) were used to determine downward advection and diffusion. Changes in ${ }^{15} \mathrm{~N}$ recovery in a $10 \mathrm{~cm}$ diameter sediment ring surrounding the core (.....) (corrected for denitrification losses) were used to measure horizontal advection and diffusion. Sedimentwater exchanges were determined from the differences in ${ }^{15} \mathrm{~N}$ loss rates between conditions of tidal inundation and exposure. Translocation losses were measured in aboveground biomass harvested in a $20 \mathrm{~cm}$ diameter area (- * - - )

${ }^{15} \mathrm{~N}$ losses are summarized in Table 3

Study site. Great Sippewissett Marsh (Cape Cod, MA, USA) is a typical New England saltmarsh dominated by the short form of Spartina alterniflora (Loisel.) growing in near-monospecific stands on the marsh plain (Teal \& Howes 1996). The sediments consist of a highly organic peat ( 21 to $35 \%$ C) of low hydraulic conductivity (Redfield 1972, Howes \& Goehringer 1994). Nitrification and denitrification are tightly coupled in these carbon-rich sediments (Valiela \& Teal 1979, Howes \& Goehringer 1994). We performed our experiments in undisturbed stands of short-form $S$. alterniflora similar to those previously investigated in this saltmarsh (e.g. Valiela \& Teal 1979, Howes et al. 1984, 1985, 1986, White \& Howes 1994a,b, Teal \& Howes 1996), and in plots originally identical to control areas that have received high $\mathrm{N}$ and $\mathrm{P}$ fertilization for 16 to 23 yr (Valiela et al. 1973, 1975). Fertilized plots were treated with 3.7 or $11.2 \mathrm{~mol}$ organic $\mathrm{N} \mathrm{m}^{-2} \mathrm{yr}^{-1}$ (71\% as pelletized sewage sludge [6.1\% N] and $29 \%$ as urea) and $2.2 \mathrm{~mol} \mathrm{P} \mathrm{m}^{-2} \mathrm{yr}^{-1}$ (as pelletized sewage sludge and triple phosphate), applied 10 times in each growing season (May to September).

Field work. We measured ${ }^{15} \mathrm{~N}$ retention and loss rates in all seasons, with measurements concentrated in the summer (unfertilized grass stands: $\mathrm{n}=9$; fertil- ized areas: $\mathrm{n}=6$; see dates in Table 6). For each denitrification rate measurement, we first made up to 14 line injections ( 0 to $10 \mathrm{~cm}$ deep, ca. $0.5 \mathrm{~m}$ apart) of ${ }^{15} \mathrm{NH}_{4} \mathrm{Cl}$ solution into the marsh sediments, performing all work from boardwalks to avoid compaction. We followed total ${ }^{15} \mathrm{~N}$ retention for 1 to $5 \mathrm{~d}$, with measurements concentrated in the first $24 \mathrm{~h}$, by destructively sampling duplicate sediment cores for each time point (total time points $\mathrm{n}=3$ to 7 ). Immediately after injection and at each subsequent sampling time, we harvested aboveground biomass and extracted duplicate piston cores $(6.5 \mathrm{~cm}$ diameter, $15 \mathrm{~cm}$ deep) centered on randomly selected injection sites. We immediately (in the field) sectioned the sediment cores into three $5 \mathrm{~cm}$ thick layers, and packed them in dry ice to halt biological activity. This treatment lowered the temperature of sediments by $10^{\circ} \mathrm{C}$ within $6 \mathrm{~min}$. Sections were completely frozen within 20 min of collection and were kept at $-20^{\circ} \mathrm{C}$ until preparation for analysis (see below). Additional uninjected cores were collected for measurements of $\mathrm{KCl}$-extractable $\mathrm{NH}_{4}{ }^{+}(\mathrm{n}=3)$, porosity $(\mathrm{n}=3)$, and natural abundance of ${ }^{15} \mathrm{~N}(\mathrm{n}=2)$, made at $5 \mathrm{~cm}$ depth intervals (methods below). We immediately filled all core holes with sediment from an adjacent area to prevent water table disturbance and air entry into nearby injection sites.

Method verification. The line-injected tracer solution $\left(0.82 \mathrm{ml} \mathrm{cm}^{-1}\right)$ increased the sediment water content by $<3 \%$. The tracer ( 4.1 to $5.6 \mu \mathrm{mol}{ }^{15} \mathrm{NH}_{4}{ }^{+} \mathrm{cm}^{-1}$ ) increased the total sediment $\mathrm{N}$ mass by only ca. $0.1 \%$, but increased the ${ }^{15} \mathrm{~N}$ content of the recovered sediment from 0.37 at. $\%$ to ca. 0.46 at. $\%$. The tracer increased sediment $\mathrm{NH}_{4}{ }^{+}$pools by an average of 68 and $27 \%$ in natural and fertilized plots, respectively. In order to examine the effect of these short-term increases in $\mathrm{NH}_{4}{ }^{+}$availability on $D_{\mathrm{n}}$ rates, an experiment was performed comparing ${ }^{15} \mathrm{~N}$ losses in unfertilized areas at injections of 33,66, and $100 \%$ of the normal tracer addition level, representing increases in sediment $\mathrm{NH}_{4}{ }^{+}$of 43,82 , and $122 \%$, respectively.

We measured tracer retention (including all nongaseous ${ }^{15} \mathrm{~N}$ forms) in the upper $10 \mathrm{~cm}$ of the $6.5 \mathrm{~cm}$ diameter sediment cores, the site of $93 \%$ of $\mathrm{CO}_{2}$ production and $97 \%$ of the live belowground plant biomass (Fig. 1) (Howes et al. 1985, White \& Howes 1994a). We measured aboveground translocation from 
temporal changes in ${ }^{15} \mathrm{~N}$ recovery in a $20 \mathrm{~cm}$ diameter area of aboveground biomass centered on each injection site. We compared ${ }^{15} \mathrm{~N}$ losses during intervals between core samplings when the marsh surface was inundated with losses occurring during tidal exposure, in order to determine if ${ }^{15} \mathrm{~N}$ losses differed under these 2 conditions and whether sediment-water exchanges were a significant loss route. Downward tracer losses (translocation, advection, or diffusion) were determined from temporal changes in ${ }^{15} \mathrm{~N}$ recovery in the metabolically inactive 10 to $15 \mathrm{~cm}$ depth horizon. Horizontal tracer losses were determined from changes in ${ }^{15} \mathrm{~N}$ recovery (corrected for $D_{\mathrm{n}}$ losses) in a $10 \mathrm{~cm}$ diameter sediment ring collected around the $6.5 \mathrm{~cm}$ diameter sampling area (Fig. 1). Although our method for determining $D_{\mathrm{n}}$ did not depend on knowing the fate of ${ }^{15} \mathrm{~N}$ retained within the $6.5 \mathrm{~cm} \times 10 \mathrm{~cm}$ core sections, we measured the partitioning of injected ${ }^{15} \mathrm{~N}$ between aboveground biomass, live roots and rhizomes, remaining sediment, and unreacted ${ }^{15} \mathrm{NH}_{4}{ }^{+}$on 1 occasion in May after 3 and $7 \mathrm{~d}$ on duplicate cores by the methods of White \& Howes (1994a).

Laboratory incubations. We also assessed our method of measuring ${ }^{15} \mathrm{~N}$ retention and loss in greenhouse lysimeters, where only gaseous ${ }^{15} \mathrm{~N}$ losses were possible. Sediment cores from unfertilized grass stands (20.3 $\mathrm{cm}$ diameter, $\mathrm{n}=4$ ) with actively growing Spartina alterniflora were maintained in lysimeters in a greenhouse with water table levels manipulated to simulate field conditions (Arenovski \& Howes 1992, White \& Howes 1994a). Incubations were conducted in late August, as for the field incubations.

We further measured ${ }^{15} \mathrm{~N}-\mathrm{N}_{2}$ production from sediments held in vitro without normal plant function or tidal inundation. Vegetation was cut to $1 \mathrm{~cm}$, and sediment cores $(8.8 \mathrm{~cm}$ diameter $\times 14 \mathrm{~cm}$ deep, collected on 2 October 2003) were line-injected with ${ }^{15} \mathrm{NH}_{4}^{+}$ $\left(3.2 \mathrm{mmol} \mathrm{cm}{ }^{-1}\right)$ and incubated $\left(20^{\circ} \mathrm{C}\right)$ in sealed glasswalled chambers. $D_{\text {n }}$ was measured by sediment ${ }^{15} \mathrm{~N}$ $\mathrm{N}_{2}$ efflux (Finnegan 251 mass spectrometer) and as $\mathrm{N}_{2}$ flux $\left(\mathrm{O}_{2}\right.$ and $\mathrm{N}_{2}$, Shimadzu GC-14A gas chromatograph). Sediments from both control and fertilized sites were incubated in replicate chambers (4 each with $80 \% \mathrm{He} / 20 \% \mathrm{O}_{2} \quad\left[\mathrm{~N}_{2}\right.$-free to facilitate $\mathrm{N}_{2}$ detection] and 2 each with He only [to control for diffusive $\mathrm{N}_{2}$ flux from dissolved porewater $\mathrm{N}_{2}$ ]; method described in Hamersley \& Howes 2003). Gas samples were analyzed daily for $5 \mathrm{~d}$, after which the total sediment ${ }^{15} \mathrm{~N}$ content was determined as with the in situ experiments.

Calculations. ${ }^{15} \mathrm{~N}$ retention was calculated as the excess above natural abundance $(0.3663$ at. $\%, \mathrm{CV}<8 \times$ $10^{-6 \%}$ ) recovered in the $6.5 \mathrm{~cm} \times 10 \mathrm{~cm}$ sediment cores and associated aboveground biomass. The time series of destructively sampled core sections was used to determine $k_{\mathrm{T}}$, the ${ }^{15} \mathrm{~N}$ decay constant, using either an exponential or linear model. We adjusted $k_{\mathrm{T}}$ arithmetically for other measured tracer losses $\left(k_{\mathrm{L}}\right)$ (Fig. 1) to obtain the ${ }^{15} \mathrm{~N}$ decay constant for nitrificationdenitrification $\left(k_{\mathrm{D}}\right.$, expressed as $\left.\% \mathrm{~d}^{-1}\right)$ :

$$
k_{\mathrm{D}}=-100\left(k_{\mathrm{T}}-k_{\mathrm{L}}\right)
$$

In the in vitro experiment, $k_{\mathrm{D}}$ was calculated from the ratio of the production rate of ${ }^{15} \mathrm{~N}-\mathrm{N}_{2}$ and the mass of tracer ${ }^{15} \mathrm{~N}$ injected into the core. Since coupled nitrification-denitrification rates of ${ }^{14} \mathrm{NH}_{4}{ }^{+}$and ${ }^{15} \mathrm{NH}_{4}{ }^{+}$do not significantly differ (in situ isotopic fractionation $[\alpha]$ of $\mathrm{NH}_{4}{ }^{+}$by nitrification-denitrification in sediments = 0.993; Brandes \& Devol 1997), $D_{\mathrm{n}}$ was calculated by applying the decay constant $k_{\mathrm{D}}$ to the in situ sediment $\mathrm{NH}_{4}{ }^{+}$pool (KCl-extractable) (White \& Howes 1994a) such that:

$$
D_{\mathrm{n}}=k_{\mathrm{D}}\left[\mathrm{NH}_{4}^{+}\right]
$$

All correlation coefficients (R) are Pearson product moment correlations, and errors are standard errors (SE).

Analytical approach. For our total ${ }^{15} \mathrm{~N}$ retention measurements, the $\mathrm{pH}$ of previously frozen core sections was reduced to ca. 2 by shaking with $0.2 \mathrm{~N}$ $\mathrm{H}_{2} \mathrm{SO}_{4}$ for $24 \mathrm{~h}$ at $4^{\circ} \mathrm{C}$. This was the best method found to inhibit biological activity during wet sample processing and prevent ${ }^{15} \mathrm{NH}_{4}{ }^{+}$volatilization during subsequent drying (to constant weight: ca. $48 \mathrm{~h}$ at $\left.60^{\circ} \mathrm{C}\right) .{ }^{15} \mathrm{~N}$ recovery from sediment sections injected with tracer in the laboratory averaged $104 \pm 1 \%$ (n = 12). Sediments and dried aboveground biomass were milled (Cyclotec) to $<0.5 \mathrm{~mm}$, and total $\mathrm{N}$ and ${ }^{15} \mathrm{~N}$ content was determined by mass spectrometry (Carlo Erba T1500, Stable Isotope Facility, University of California, Davis). This analysis measured all nongaseous forms of ${ }^{15} \mathrm{~N}$ (including belowground plant and microbial biomass) within the core sections. $\mathrm{KCl}-$ extractable $\mathrm{NH}_{4}^{+}$('sediment $\mathrm{NH}_{4}{ }^{+\prime}$ ) was determined by extraction of known sediment volumes with acidified $(\mathrm{pH}=2) 2 \mathrm{~N} \mathrm{KCl}$ at $4^{\circ} \mathrm{C}$ for $24 \mathrm{~h}$ (White \& Howes 1994a), followed by sterile filtration and analysis by a colorimetric indophenol method (Scheiner 1976). The longer extraction times required for these peats are preferable to homogenization and do not result in $\mathrm{NH}_{4}^{+}$mineralization (authors' unpubl. data). Known volumes of sediment were weighed wet and dry (to constant weight at $60^{\circ} \mathrm{C}$ ) to determine porosity and density. Organic $\mathrm{C}$ and $\mathrm{N}$ contents were determined by elemental analysis (PerkinElmer 2400). Porewaters were extracted with sippers and analyzed for salinity (conductivity) and sulfide (Cline 1969). 
Table 1. Characteristics of unfertilized and XF fertilized (11.2 mol organic $\mathrm{N} \mathrm{m}^{-2} \mathrm{yr}^{-1}$ for 16 to $23 \mathrm{yr}$ ) marsh plots. Standard errors in parentheses

\begin{tabular}{|c|c|c|c|}
\hline & Unit & Unfertilized & XF fertilized \\
\hline \multicolumn{4}{|c|}{ Sediments (top $10 \mathrm{~cm})^{\mathrm{a}}$} \\
\hline Porosity & $\mathrm{ml} \mathrm{cm}^{-3}$ & $0.86(0.01)$ & $0.80(0.01)$ \\
\hline Density & $\mathrm{g} \mathrm{cm}^{-3}$ & $0.16(0.01)$ & $0.21(0.01)$ \\
\hline Organic N & $\mathrm{mmol} \mathrm{cm}-3$ & $0.16(0.01)$ & $0.34(0.02)$ \\
\hline Organic C & $\mathrm{mmol} \mathrm{cm}-3$ & $3.1(0.1)$ & $3.9(0.2)$ \\
\hline \multicolumn{4}{|c|}{ KCl-extractable $\mathrm{NH}_{4}^{+}$} \\
\hline $0-5 \mathrm{~cm}$ & & $0.13(0.02)$ & $0.84(0.33)$ \\
\hline $5-10 \mathrm{~cm}$ & & $0.15(0.04)$ & $0.70(0.25)$ \\
\hline $10-15 \mathrm{~cm}$ & & $0.12(0.04)$ & $0.55(0.16)$ \\
\hline Porewater salinity & & $26.2(2.9)$ & $28.4(2.9)$ \\
\hline Porewater $\mathrm{S}^{2-}$ & $\mathrm{mM}$ & $1.66(0.50)$ & $0.42(0.15)$ \\
\hline \multicolumn{4}{|l|}{ Spartina alterniflora ${ }^{\mathrm{b}}$} \\
\hline Stem height & $\mathrm{cm}$ & 30 & 102 \\
\hline Peak biomass & $\mathrm{g} \mathrm{m}^{-2}$ & $270(66)$ & $1100(90)$ \\
\hline \multicolumn{4}{|c|}{$\begin{array}{l}{ }^{a} n>24 \text { (unfertilized) and } n>18 \text { (fertilized) } \\
{ }^{b} \text { Howes et al. (1986) }\end{array}$} \\
\hline
\end{tabular}

\section{RESULTS}

Fertilization resulted in a $>3$-fold increase in the aboveground biomass and height of Spartina alterniflora plants over control areas (Table 1). Sediment characteristics also differed; fertilized sediments were denser and contained nearly twice the organic $\mathrm{N}$ and $>4$ times the $\mathrm{NH}_{4}{ }^{+}$. Although sediment salinity levels were similar, aeration of the sediments by increased evapotranspiration reduced porewater $\mathrm{S}^{2-}$ concentrations nearly 4 -fold.

\section{Evaluation of the in situ method}

Line-injections of ${ }^{15} \mathrm{NH}_{4}{ }^{+}$into undisturbed Spartina alterniflora saltmarsh sediments resulted in a reproducible distribution of label through the sediment, and most of the label was recovered at $T_{0}$ within the $6.5 \mathrm{~cm}$ diameter sediment core. The ${ }^{15} \mathrm{~N}$ recovery at $T_{0}$ averaged $99 \%$ in unfertilized and $98 \%$ in fertilized sediments within a $5 \mathrm{~cm}$ radius $(10 \mathrm{~cm}$ diameter) of the injection site (Table 2, Fig. 1). Most (ca. 93\%) of the injected ${ }^{15} \mathrm{~N}$ was recovered within a $6.5 \mathrm{~cm}$ diameter area in both sediment types, and only $6.2 \pm 1.8$ and 5.4 $\pm 1.8 \%$ was recovered outside of the $6.5 \mathrm{~cm}$ diameter sample core in unfertilized and fertilized sediments, respectively. The distribution of recovered ${ }^{15} \mathrm{~N}$ at each depth interval was consistent within sediment type (unfertilized versus fertilized). Some ${ }^{15} \mathrm{~N}$ was recovered in the 10 to $15 \mathrm{~cm}$ depth layer since the line injection was begun with the syringe needle tip at $10 \mathrm{~cm}$.

Non-denitrification ${ }^{15} \mathrm{~N}$ loss routes were small relative to total losses (Table 3). Measurements made on each sampling date were used to calculate $k_{\mathrm{L}}$ (Eq. 1).
Overall, downward losses of ${ }^{15} \mathrm{~N}$ were not significant (unfertilized sediments: mean $=-2.0 \pm 5.4 \% \mathrm{~d}^{-1}, t=1.2, \mathrm{df}=8$, $\mathrm{p}=0.27$; fertilized sediments: mean $=$ $\left.4.1 \pm 9.8 \% \mathrm{~d}^{-1}, t=0.55, \mathrm{df}=5, \mathrm{p}=0.6\right)$. Horizontal losses of ${ }^{15} \mathrm{~N}$ through the sediments averaged only $1.8 \pm 0.7 \% \mathrm{~d}^{-1}$ ( $\mathrm{n}=8$ ) in unfertilized sediments and $1.7 \pm 0.5 \% \mathrm{~d}^{-1}(\mathrm{n}=6)$ in fertilized sediments. Sediment-water exchanges during tidal inundation were not significant either $\left(0.5 \pm 13 \% \mathrm{~d}^{-1}, t=0.005\right.$, $\mathrm{df}=6, \mathrm{p}=0.5$ ). The large error associated with the sediment-water exchanges results exists because they were determined from the differences between $2{ }^{15} \mathrm{~N}$ recovery measurements typically only hours apart (Fig. 2). Translocation of ${ }^{15} \mathrm{~N}$ into aboveground biomass during the first $24 \mathrm{~h}$ was small, averaging $0.9 \pm 1.4 \% \mathrm{~d}^{-1}(\mathrm{n}=9)$ in unfertilized and 2.0 $\pm 0.8 \% \mathrm{~d}^{-1}(\mathrm{n}=6)$ in fertilized sediments (December excluded [no translocation]). Since changes in the aboveground biomass pool were included in $k_{\mathrm{T}}$ and sediment-water exchanges were not significant, $k_{\mathrm{L}}$ was calculated as the sum of the measured horizontal and vertical losses. The overall mean rate of horizontal movement of ${ }^{15} \mathrm{~N}$ was used to calculate $k_{\mathrm{L}}$ when actual measurements during 3 sampling dates were not made.

Enhancement of sediment $\mathrm{NH}_{4}{ }^{+}$pools by the ${ }^{15} \mathrm{NH}_{4}{ }^{+}$ tracer had no significant effect on the decay constant $k_{\mathrm{D}}$ or, therefore, on $D_{\mathrm{n}}$ rates (Fig. 2). Measurements at tracer injection levels $(33,66$, and $100 \%$ of normal tracer addition levels) representing sediment $\mathrm{NH}_{4}{ }^{+}$ pool enhancements of 43,82 , and $122 \%$, respectively, resulted in $k_{\mathrm{D}}$ values of $71 \pm 5,72 \pm 23$, and $73 \pm 10 \% \mathrm{~d}^{-1}$,

Table 2. Mean ${ }^{15} \mathrm{~N}$ recovery (SE) in sediments sampled from unfertilized and XF fertilized (11.2 mol organic $\mathrm{N} \mathrm{m}^{-2} \mathrm{yr}^{-1}$ ) saltmarsh grass stands ca. 30 min after line-injecting ${ }^{15} \mathrm{NH}_{4}{ }^{+}$ solution into undisturbed sediments $(0$ to $10 \mathrm{~cm})$

\begin{tabular}{|lcc|}
\hline & \multicolumn{2}{c|}{$\begin{array}{c}{ }^{15} \mathrm{~N} \text { recovered at } T_{0} \\
(\% \text { of total injected })\end{array}$} \\
\hline $\begin{array}{l}\text { Depth interval } \\
(6.5 \mathrm{~cm} \text { diameter core })^{\mathrm{a}}\end{array}$ & Unfertilized & XF fertilized \\
& & \\
$0-5 \mathrm{~cm}$ & $38.3(3.8)$ & $37.7(4.0)$ \\
$5-10 \mathrm{~cm}$ & $40.6(3.3)$ & $49.2(3.8)$ \\
$10-15 \mathrm{~cm}$ & $13.8(2.5)$ & $5.8(1.8)$ \\
Subtotal & $92.8(4.5)$ & $92.7(1.4)$ \\
Outside $6.5 \mathrm{~cm}$ diameter core ${ }^{\mathrm{b}}$ & $6.2(1.8)$ & $5.4(1.8)$ \\
Total & 99.0 & 98.0 \\
${ }^{\mathrm{a}} \mathrm{n}=18$ (unfertilized) and $\mathrm{n}=12$ (fertilized) & \\
${ }^{\mathrm{b}} 10 \mathrm{~cm}$ diameter outer core taken surrounding $6.5 \mathrm{~cm}$ dia- \\
meter inner core, $\mathrm{n}=8$ (unfertilized) and $\mathrm{n}=6$ (fertilized) \\
\hline
\end{tabular}


Table 3. Mean ${ }^{15} \mathrm{~N}$ losses (SE) from vegetated saltmarsh sediment volumes $(6.5 \mathrm{~cm}$ diameter $\times 10 \mathrm{~cm})$ injected in situ with ${ }^{15} \mathrm{NH}_{4}{ }^{+}$. Losses are expressed as a percentage of injected ${ }^{15} \mathrm{~N}$ lost in the first $24 \mathrm{~h}$ and can be compared with denitrification loss rates $\left(k_{\mathrm{D}}\right)$ (see Table 6). Results from an earlier study (White \& Howes 1994a) are included, with the time span of measurements within square brackets. Positive values indicate a loss

\begin{tabular}{|c|c|c|c|}
\hline \multirow[b]{2}{*}{${ }^{15} \mathrm{~N}$ loss route (Fig. 1 ) } & \multirow[b]{2}{*}{ Method of measurement } & \multicolumn{2}{|c|}{${ }^{15} \mathrm{~N}$ loss rate } \\
\hline & & Unfertilized & XF fertilized \\
\hline \multirow[t]{2}{*}{$\begin{array}{l}\text { Downward advection } \\
\text { and diffusion }\end{array}$} & $\begin{array}{c}\text { Change in } \begin{array}{c}{ }^{15} \mathrm{~N} \text { recovery below injection } \\
\text { depth }(10 \mathrm{~cm})\end{array}\end{array}$ & $-2.0(5.4) \% \mathrm{~d}^{-1}$ & $4.1(9.8) \% \mathrm{~d}^{-1}$ \\
\hline & $\begin{array}{l}\text { Change in }{ }^{15} \mathrm{~N} \text { recovery below injection } \\
\text { depth }(15 \mathrm{~cm}) \text { in undisturbed field sites }{ }^{\mathrm{a}}\end{array}$ & $0(1.4) \%[3 \mathrm{~d}]$ & \\
\hline \multirow[t]{2}{*}{$\begin{array}{l}\text { Horizontal advection } \\
\text { and diffusion }\end{array}$} & $\begin{array}{c}\text { Change in }{ }^{15} \mathrm{~N} \text { recovery in } 10 \mathrm{~cm} \text { diameter } \\
\text { outer sediment ring }\end{array}$ & $1.8(0.7) \% \mathrm{~d}^{-1}$ & $1.7(0.5) \% \mathrm{~d}^{-1}$ \\
\hline & $\begin{array}{c}\text { Difference in }{ }^{15} \mathrm{~N} \text { recovery between } \\
\text { undisturbed field sites and } \\
\text { open-bottomed in situ lysimeters }{ }^{\mathrm{a}}\end{array}$ & $-6.2 \%[100 \mathrm{~d}]$ & \\
\hline \multirow[t]{2}{*}{$\begin{array}{l}\text { Sediment-water } \\
\text { exchanges }\end{array}$} & $\begin{array}{l}\text { Difference in }{ }^{15} \mathrm{~N} \text { loss rates between } \\
\text { inundated and exposed conditions }\end{array}$ & $0.5(13) \% \mathrm{~d}^{-1}$ & $0.5(13) \% \mathrm{~d}^{-1}$ \\
\hline & $\begin{array}{l}\text { Difference in }{ }^{15} \mathrm{~N} \text { recovery between } \\
\text { in situ and laboratory lysimeters }{ }^{\mathrm{a}}\end{array}$ & $-3.1 \%[30 \mathrm{~d}]$ & \\
\hline Translocation & ${ }^{15} \mathrm{~N}$ recovery in aboveground biomass & $0.9(1.4) \% \mathrm{~d}^{-1}$ & $2.0(0.8) \% \mathrm{~d}^{-1}$ \\
\hline
\end{tabular}

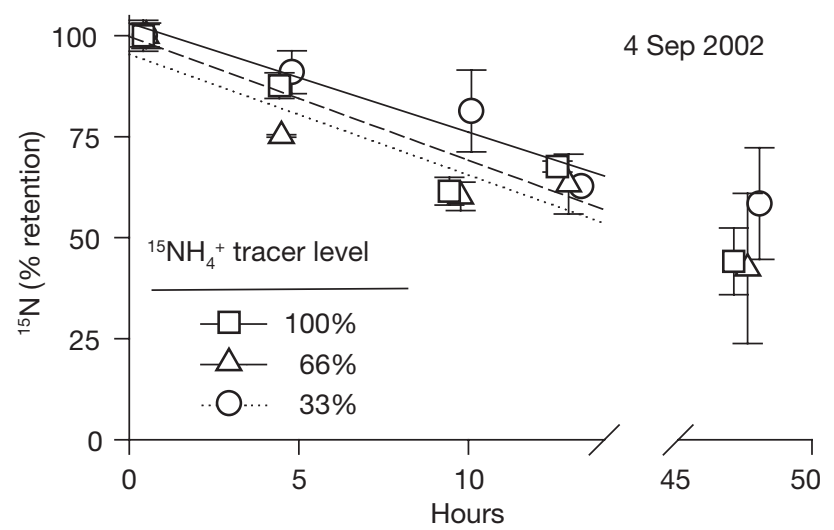

Fig. 2. ${ }^{15} \mathrm{~N}$ decay constant in in situ incubations is independent of initial ${ }^{15} \mathrm{NH}_{4}{ }^{+}$tracer concentration. Short-term in situ ${ }^{15} \mathrm{~N}$ recovery from unfertilized vegetated saltmarsh sediments with ${ }^{15} \mathrm{NH}_{4}{ }^{+}$added at 33,66 , and $100 \%$ of standard injection levels $\left(4.6 \mathrm{mmol}^{15} \mathrm{NH}_{4}{ }^{+} \mathrm{Cm}^{-1}\right)$. ${ }^{15} \mathrm{~N}$ recovery includes aboveground biomass. The ${ }^{15} \mathrm{~N}$ decay constants $\left(k_{\mathrm{D}}\right.$, Eq. 1$)$ were independent of the tracer addition level $\left(71 \pm 5 \% \mathrm{~d}^{-1}\right.$, $72 \pm 8 \% \mathrm{~d}^{-1}$, and $73 \pm 10 \% \mathrm{~d}^{-1}$, respectively). Error bars are $\mathrm{SE}(\mathrm{n}=2)$

respectively (1-way ANCOVA test for homogeneity of regressions, $\mathrm{df}=2,6, \mathrm{p}=0.99$ ).

The pattern of loss and retention of the ${ }^{15} \mathrm{~N}$ label was similar to that observed previously (White \& Howes 1994a), with initial rapid losses slowing as the ${ }^{15} \mathrm{NH}_{4}{ }^{+}$ label became incorporated into plant biomass (Fig. 3). Although most of the retained ${ }^{15} \mathrm{~N}$ was bound up in plant biomass after $3 \mathrm{~d}$, aboveground translocation was relatively small, varying from 1 to $6 \%$ during the growing season (Fig. 4), similar to earlier observations (White \& Howes 1994a). Of the recovered label, 81\% was found in live roots and rhizomes (Fig. 3). More ${ }^{15} \mathrm{~N}$ was translocated to aboveground Spartina alterniflora biomass in fertilized grass stands than was translocated in unfertilized control stands.

Late summer comparisons of $D_{\mathrm{n}}$ measured in situ and in greenhouse lysimeters (with growing plants and simulated tidal cycles in which denitrification was the only possible ${ }^{15} \mathrm{~N}$ loss route) were similar $(6.9 \pm 1.9$ versus $8.3 \pm 2.1 \mathrm{mmol} \mathrm{N} \mathrm{m}{ }^{-2} \mathrm{~d}^{-1}$; Table 4 ), confirming that no significant loss terms were unaccounted for by our method. However, when sediments were incubated in vitro with disrupted plant activity and no tidal cycles, $D_{\mathrm{n}}$ became insignificant in unfertilized and very low in fertilized sediments, although oxygen uptake rates were similar to those reported earlier for this same marsh (Table 5; Howes et al. 1984).

\section{Nitrification-denitrification}

We measured $D_{\mathrm{n}}$ rates in both unfertilized and fertilized grass stands. We made late-summer measurements in each year from 1997 to 2000, and collected seasonal data over $2 \mathrm{yr}$ (see dates in Table 6). The short-term time course of ${ }^{15} \mathrm{~N}$ retention in the Spartina alterniflora stands within Great Sippewissett Marsh yielded a temporal pattern consistent with coupled nitrification-denitrification losses (Fig. 5). After an initial period of rapid ${ }^{15} \mathrm{~N}$ loss, short-term nitrification-denitrification losses of ${ }^{15} \mathrm{~N}$ slowed, as the ${ }^{15} \mathrm{NH}_{4}{ }^{+}$ tracer became incorporated into biomass and was less available to support $D_{\mathrm{n}}$ (Figs. 3 \& 4). In unfertilized $S$. alterniflora stands, the ${ }^{15} \mathrm{~N}$ decay constant due to 




Fig. 5. Examples of ${ }^{15} \mathrm{~N}$ recovery time courses (within $6.5 \mathrm{~cm}$ diameter $\times 10 \mathrm{~cm}$ sediment volume plus aboveground biomass) in incubations with ${ }^{15} \mathrm{NH}_{4}{ }^{+}$in undisturbed natural (unfertilized) and fertilized (11.2 mol organic $\mathrm{N} \mathrm{m}^{-2} \mathrm{yr}^{-1}$ ) saltmarsh grass stands. The initial rapid loss of ${ }^{15} \mathrm{~N}$ due to denitrification slows after ${ }^{15} \mathrm{NH}_{4}{ }^{+}$becomes fixed into biomass pools with slow turnover (Fig. 3). Error bars are SE ( $n=2)$

added in excess of plant growth (and competitive interactions would not be expected to dominate), nitrification-denitrification losses reflected seasonal patterns of $\mathrm{N}$ addition and/or temperature (Fig. 6B).

\section{Non-denitrification ${ }^{15} \mathrm{~N}$ losses}

\footnotetext{
${ }^{15} \mathrm{~N}$ measures of nitrogen loss from saltmarsh sediments would ideally include recovery of ${ }^{15} \mathrm{~N}-\mathrm{N}_{2}$ for a complete mass balance. However, complete ${ }^{15} \mathrm{~N}$ recovery is not possible without experimental conditions that disturb plant growth, evapotranspiration, and tidal cycles. In order to constrain uncertainties in the fate of missing ${ }^{15} \mathrm{~N}$, we performed experiments (White \& Howes $1994 \mathrm{a}$, this paper) to measure the magnitude and significance of non- $D_{\mathrm{n}}$ loss routes (Fig. 1, Table 3 ). $D_{\mathrm{n}}$ rates measured in situ and in greenhouse lysimeters where $D_{\mathrm{n}}$ was the only possible ${ }^{15} \mathrm{~N}$ loss route were similar (Table 4), as were their patterns of long-term ${ }^{15} \mathrm{~N}$ retention (in experiments by White \& Howes 1994a). In contrast, in plant-free sediments incubated in vitro, $D_{\mathrm{n}}$ was nearly zero, possibly because of the reduction in oxygen transport into the sediments when evapotranspiration and leakage of $\mathrm{O}_{2}$ from roots were suppressed under in vitro conditions (Table 4) (Dacey \& Howes 1984, Howes \&
}
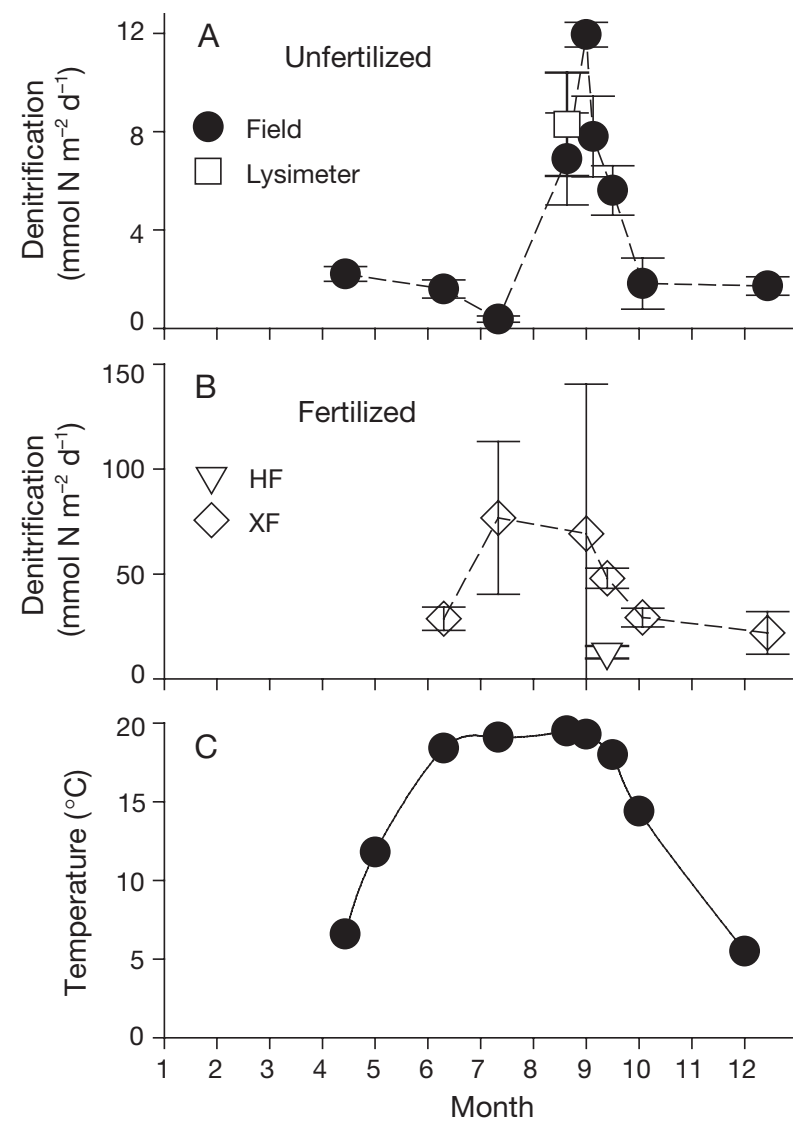

Fig. 6. Denitrification rates in Spartina alterniflora stands in the Great Sippewissett saltmarsh. Rates were measured in different years; see Table 6 for sampling dates. Note differing $y$-axis scales in Panels A and B. (A) Natural unfertilized areas. (B) Fertilized areas (XF: $11.2 \mathrm{~mol}$ organic $\mathrm{N} \mathrm{m}^{-2} \mathrm{yr}^{-1}$; HF: $3.7 \mathrm{~mol}$ organic $\left.\mathrm{N} \mathrm{m}^{-2} \mathrm{yr}^{-1}\right)$. Error bars are $\mathrm{SE}(\mathrm{n}=2)$. (C) Seasonal sediment temperature in natural unfertilized grass stands

Teal 1994). Although sediment $\mathrm{NH}_{4}{ }^{+}$levels differed among the 3 incubation conditions that we compared (Table 4), we do not believe that these differences explain the $D_{\mathrm{n}}$ rates we measured. Sediment $\mathrm{NH}_{4}{ }^{+}$levels in both the in situ and in vitro treatments were within the range of sediment $\mathrm{NH}_{4}{ }^{+}$levels measured during the growing season in the field (Table 6), and there was little correlation of sediment $\mathrm{NH}_{4}{ }^{+}$with $D_{\mathrm{n}}(\mathrm{R}=-0.05)$. That no $D_{\mathrm{n}}$ was measured in the in vitro treatment was more likely a result of the experimental conditions required for In vitro measurement than the sediment $\mathrm{NH}_{4}{ }^{+}$level. In the in vitro measurement, it was necessary to remove the aboveground biomass (typically 30 to $40 \mathrm{~cm}$ tall) in order to have a small headspace to increase the sensitivity of ${ }^{15} \mathrm{~N}-\mathrm{N}_{2}$ production. In this, we followed the practice of all previous saltmarsh investigators (see Table 7). In addition, in the water-saturated atmosphere of an in vitro chamber, the absence of evapotranspiration prevents sediment aeration, likely inhibiting nitrification (Dacey \& Howes 1984). 
Table 7. Denitrification rates determined in saltmarsh sediments

\begin{tabular}{|c|c|c|c|c|c|}
\hline $\begin{array}{c}\text { Den } \\
\left(\mathrm{mmol} \mathrm{N} \mathrm{m}^{-2} \mathrm{~d}^{-1}\right)\end{array}$ & $\begin{array}{l}\text { itrification- } \\
\text { Annually integrated } \\
\quad\left(\mathrm{mol} \mathrm{N} \mathrm{m}^{-2} \mathrm{yr}^{-1}\right)\end{array}$ & Method & Vegetation & $\begin{array}{l}\text { Experimental } \\
\text { conditions }\end{array}$ & Source \\
\hline $0.4-11.9$ & 0.77 & ${ }^{15} \mathrm{NH}_{4}{ }^{+}$retention & Short Spartina alterniflora & In situ, plants & Present study \\
\hline 1.8 & $0.29-0.40$ & $\begin{array}{l}{ }^{15} \mathrm{NH}_{4}{ }^{+} \text {retention } \\
\text { mass balance }\end{array}$ & Short $S$. alterniflora & In situ, plants & White \& Howes (1994a) \\
\hline 2.3 & - & Sediment $\mathrm{N}_{2}$ profiles & S. alterniflora & In situ & Haines et al. (1977) \\
\hline $0.4-2.1$ & 0.40 & $\mathrm{~N}_{2}$ production & Short $S$. alterniflora & In situ, no plants & Kaplan et al. (1979) \\
\hline 0.21 & - & $\begin{array}{l}{ }^{15} \mathrm{~N}_{2} \text { generated from } \\
{ }^{15} \mathrm{NO}_{3}^{-}\end{array}$ & $\begin{array}{l}\text { Puccinellia maritima } \\
\text { S. townsendii } \\
\text { Halimione portulacoides }\end{array}$ & In vitro, no plants & $\begin{array}{l}\text { Abd Aziz \& } \\
\text { Nedwell (1986) }\end{array}$ \\
\hline- & 0.29 & $\begin{array}{l}\mathrm{N}_{2} \mathrm{O} \text {, corrected for } \\
\mathrm{N}_{2} / \mathrm{N}_{2} \mathrm{O} \text { ratio }\end{array}$ & S. alterniflora & In situ & DeLaune et al. (1989) \\
\hline $0.06-1.4$ & - & Acetylene block & H. portulacoides & In vitro, no plants & Koch et al. (1992) \\
\hline $0-0.61$ & - & Acetylene block & S. alterniflora & In vitro, no plants & Thompson et al. (1995) \\
\hline- & 0.043 & ${ }^{15} \mathrm{~N}_{2} \mathrm{O}$ isotope dilution & Short $S$. alterniflora & In vitro, no plants & Anderson et al. (1997) \\
\hline 423 & - & $\begin{array}{l}\text { Acetylene block } \\
\text { short } S \text {. alterniflora }\end{array}$ & S. cynosuroides, & In vitro, no plants & Tobias et al. (2001b) \\
\hline $0-2.2$ & & Isotope pairing & Limonium serotinum & In vitro, no plants & Eriksson et al. (2003) \\
\hline-9.0 to 10.1 & & $\begin{array}{l}\mathrm{N}_{2} \text { changes in over- } \\
\text { lying water exposed } \\
\text { to atmosphere }\end{array}$ & $\begin{array}{l}\text { S. patens, } \\
\text { Schoenplectus } \\
\text { pungens }\end{array}$ & In vitro, plants & Davis et al. (2004) \\
\hline $5.6-13.8$ & & Acetylene block & Short S. alterniflora & In vitro, no plants & Dollhopf et al. (2005) \\
\hline
\end{tabular}

Specific measurements of potential ${ }^{15} \mathrm{~N}$ loss routes confirmed that they were small relative to denitrification losses, supporting earlier work (Table 3; White \& Howes 1994a). Losses through diffusion and advection are small because the ${ }^{15} \mathrm{NH}_{4}{ }^{+}$label rapidly exchanges with 'bound' porewater and sorbed $\mathrm{NH}_{4}{ }^{+}$ pools, and the specific yield of porewater the pool for which movement is possible) is only 1 to $3 \%$ of the total water content (Dacey \& Howes 1984, White \& Howes 1994a). Further, the hydraulic conductivity of these marsh peats is low, making significant tracer movement unlikely (Howes \& Goehringer 1994). Any physical processes responsible for ${ }^{15} \mathrm{~N}$ loss from sediments (horizontal and vertical losses through the sediments and losses during tidal inundation) would likely be similar, not only across seasons, but between fertilized and unfertilized sediments (Table 3). Nevertheless, in our experiments, strong differences in $D_{\mathrm{n}}$ (>3-fold) were seen between seasons, and annual losses in fertilized sediments were 13-fold greater than in unfertilized sediments. Any unaccounted for physical processes leading to loss were therefore small enough to allow this seasonal and experimental variation to be measured. However, non-denitrification ${ }^{15} \mathrm{~N}$ loss routes and the errors associated with them (Table 3) were significant relative to the $D_{\mathrm{n}}$ losses in unfertilized grass stands from October to July (Table 6), and the variation in $D_{\mathrm{n}}$ rates during this period (Fig. 6A) is likely not significant.

\section{Plant uptake}

Translocation of ${ }^{15} \mathrm{~N}$ into aboveground biomass peaked in July (Fig. 4). However, recovery of ${ }^{15} \mathrm{~N}$ in aboveground biomass never exceeded $6 \%$. Nonetheless, plant uptake accounted for a significant proportion of the ${ }^{15} \mathrm{~N}$ pool retained within the $6.5 \mathrm{~cm} \times 10 \mathrm{~cm}$ core section after $3 \mathrm{~d}$ in May, with $81 \%$ of the retained label found in plant biomass (Fig. 3). The ratio between the recovery of ${ }^{15} \mathrm{~N}$ in above- and belowground plant biomass after $3 \mathrm{~d}$ (about 10\%) was similar to the ratio of annual plant production measured previously in the same marsh (Valiela et al. 1976). Translocation from the injection site into a $10 \mathrm{~cm}$ diameter ring around the sampled $6.5 \mathrm{~cm}$ diameter core was $<1.8 \% \mathrm{~d}^{-1}$. Translocation of ${ }^{15} \mathrm{~N}$ outside of this $10 \mathrm{~cm}$ diameter sampled sediment area was likely even lower, and not likely an important loss route, since although translocation and belowground biomass growth were highest in July and June, losses of ${ }^{15} \mathrm{~N}$ in unfertilized grass stands at this time were very low (Fig. 4; Valiela et al. 1976).

\section{Nitrification-denitrification}

The pattern of $D_{\mathrm{n}}$ in natural unfertilized Spartina alterniflora grass stands did not appear to be forced primarily by sediment temperature (Fig. 6A,C). Although sediment temperature reached its summer plateau by June, $D_{\mathrm{n}}$ rates in June and July were low, 
similar to the rates measured at other times of the year. $D_{\mathrm{n}}$ in these saltmarsh grass stands is likely controlled by ${ }^{15} \mathrm{NH}_{4}{ }^{+}$availability (Hamersley \& Howes 2003), which itself is regulated by the turnover of belowground plant biomass. Although $\mathrm{KCl}$-extractable $\mathrm{NH}_{4}{ }^{+}$ pools in the sediment did not show any seasonal trend (Table 6), the availability of $\mathrm{NH}_{4}{ }^{+}$may have changed in late summer as a result of changes in organic matter degradation or of competition for regenerated $\mathrm{NH}_{4}{ }^{+}$ between plants and nitrifiers. The large and rapid incorporation of label into plant biomass in May (Fig. 3) suggests that plant $\mathrm{N}$ uptake competes with nitrification-denitrification for remineralized $\mathrm{NH}_{4}{ }^{+}$early in the growing season, reducing the availability of $\mathrm{N}$ for denitrification (Valiela et al. 1975, DeLaune et al. 1983, Anderson et al. 1997). Measures of above- and belowground plant biomass indicate that plant growth stops in late summer and belowground biomass begins to decrease (Valiela et al. 1976). Sediment organic matter degradation (and $\mathrm{NH}_{4}{ }^{+}$regeneration) peaks sharply during August and falls rapidly during September (Teal \& Howes 1996). Therefore, the late summer peak in $D_{\mathrm{n}}$ is likely fueled by this increase in $\mathrm{NH}_{4}{ }^{+}$availability. The importance of $S$. alterniflora $\mathrm{N}$ uptake in limiting nitrification-denitrification losses has also been shown in experiments with ${ }^{15} \mathrm{NH}_{4}{ }^{+}$where ${ }^{15} \mathrm{~N}$ retention in the presence of living marsh plants was higher than that in sediments without plants (Buresh et al. 1981, Dean \& Biesboer 1985). Competition between plants and nitrifiers for uptake of limiting quantities of $\mathrm{N}$ is also known from a variety of other systems, including seagrass meadows and hardwood forests (Zak et al. 1990, Welsh et al. 2000), as well as in monospecific pot experiments (Verhagen et al. 1995, Norton \& Firestone 1996, Bodelier et al. 1998).

The range of denitrification rates measured in unfertilized grass stands in the present study is within the range reported with older methods (Table 7). Most in vitro measurements were lower than the in situ measurements, probably due to anoxic sediment conditions in in vitro studies, which inhibited nitrification. Denitrification rates determined by the acetylene block method were usually much lower than those determined by other methods, as expected from the known limitations of this technique and the inhibition of nitrification by acetylene. Our annual rate $(0.77 \mathrm{~mol}$ $\mathrm{N} \mathrm{m}^{-2} \mathrm{yr}^{-1}$ ) represents a significant increase from the annual denitrification flux (0.29 to $0.40 \mathrm{~mol} \mathrm{~N} \mathrm{~m}^{-2} \mathrm{yr}^{-1}$ ) used by White \& Howes (1994a) in their $\mathrm{N}$ budget of the short Spartina alterniflora marsh, which assumed no denitrification during the coldest 6 mo of the year. In contrast, our study showed denitrification losses from April to December (the entire period we measured). We assumed no denitrification only for the 2 mo during which the marsh sediments are typically frozen.
In addition, previous measurements did not capture the denitrification peak in late August and early September, which accounted for nearly half of our measured annual flux. Although our integrated annual denitrification rate in unfertilized grass stands is higher than suggested by mass balance measures, changing our assumption of linearity between measurements and rejecting the highest point yields an annual rate of $0.59 \mathrm{~mol} \mathrm{~N} \mathrm{~m}^{-2} \mathrm{yr}^{-1}$, a value more closely in line with mass balance estimates.

In fertilized marsh areas, however, $D_{\mathrm{n}}$ rates appeared to be controlled primarily by the high $\mathrm{N}$ availability resulting from fertilization. Competition with plant $\mathrm{N}$ uptake was less important, since the added $\mathrm{N}$ was $>10$ times the plant demand (White \& Howes 1994b). In July and early September, sediment $\mathrm{NH}_{4}{ }^{+}$ concentration was $>10$ times higher than in unfertilized sediments (Table 6 ), and $D_{\mathrm{n}}$ rates were similarly enhanced (Fig. 6B). However, although sediment temperature was high in June, both sediment $\mathrm{NH}_{4}{ }^{+}$and $D_{\mathrm{n}}$ remained low. Little fertilizer (3.1 $\mathrm{mol} \mathrm{N} \mathrm{m}^{-2}$ ) had been applied at this point, and there may not have been enough time for the fertilizer $\mathrm{N}$ to penetrate into actively cycling sediment zones. Additionally, high plant uptake early in the growing season could have accounted for as much as one-third of the applied fertilizer, further reducing its influence on sediment $\mathrm{NH}_{4}{ }^{+}$ availability (based on measured aboveground biomass $\mathrm{N}$ and a belowground:aboveground $\mathrm{N}$ ratio of 2.4; Valiela et al. 1976, White \& Howes 1994b).

$D_{\mathrm{n}}$ rates calculated by our ${ }^{15} \mathrm{~N}$ tracer method were verified by a mass balance of $\mathrm{N}$ in the fertilized plots calculated after 16 to 23 yr of $\mathrm{N}$ amendments (authors' unpubl. data). Annual denitrification losses were assessed relative to the known addition versus retention of fertilizer $\mathrm{N}$ within the sediments, since $\mathrm{N}$ losses to tidal waters are known to be small (Valiela et al. 1973, Wolaver et al. 1983, White \& Howes 1994b). In 4 plots receiving $11.2 \mathrm{~mol} \mathrm{~N} \mathrm{~m} \mathrm{yr}^{-1}$, only $6.2 \%$ was retained in sediment pools (in excess of controls) $(n=8)$, indicating a maximum denitrification loss of $10.5 \pm 0.2 \mathrm{~mol} \mathrm{~N} \mathrm{~m}{ }^{-2} \mathrm{yr}^{-1}$, similar to the $10.5 \pm 4.9 \mathrm{~mol} \mathrm{~N} \mathrm{~m}^{-2} \mathrm{yr}^{-1}$ loss by denitrification determined from the ${ }^{15} \mathrm{NH}_{4}{ }^{+}$tracer measurements of the present study. Although the $D_{\mathrm{n}}$ rates measured in our fertilized saltmarsh grass stands are high, they are within the range of previously published rates for the vegetated saltmarsh, and rates up to $273 \mathrm{mmol} \mathrm{N}$ $\mathrm{m}^{-2} \mathrm{~d}^{-1}$ (determined by isotope-pairing) have been reported in estuarine sediments receiving similarly high inputs of anthropogenic N (Trimmer et al. 2000).

The faster turnover of ${ }^{15} \mathrm{~N}\left(k_{\mathrm{D}}\right)$ in fertilized sediments probably results from a combination of factors (Table 6). Organic N concentration and belowground biomass in fertilized sediments are more than twice those in unfertilized sediments (Table 1; Valiela et al. 
1976), and ${ }^{15} \mathrm{~N}$ turnover in fertilized sediments may have been stimulated by elevated microbial populations and the resulting rapid remineralization of plant biomass and organic fertilizer. In addition, high Spartina alterniflora growth rates under fertilization lead to increased evapotranspiration, deeper intertidal water table excursions, and increased sediment oxidation, which may stimulate nitrification rates (Dacey \& Howes 1984, Howes et al. 1986).

Our measurements of denitrification fluxes from saltmarshes are the first we know of to show a sharp increase in $D_{\mathrm{n}}$ during a brief period in late summer, rather than exhibiting the broad sinusoidal distribution that might be expected were denitrification rates primarily regulated by temperature. Our results emphasize the importance of in situ measures of denitrification in understanding the seasonal cycle of denitrification in saltmarsh grass stands. In vitro measures may overemphasize temperature effects, while neglecting the important structuring effects of sediment oxidation and plant $\mathrm{N}$ uptake on the availability of $\mathrm{NH}_{4}{ }^{+}$to support coupled nitrification-denitrification.

Acknowledgements. We thank Michael DeLeo, Marge Zinn, and numerous volunteers and interns for field and laboratory assistance. We also thank Drs. Susan and Edward Hughes for access to their saltmarsh property. David White and Craig Taylor contributed assistance and comments on an early version of the manuscript. Mark Altabet allowed us the use of his mass spectrometer. Fertilizer was donated by the Milwaukee Metropolitan Sewerage District. This project was supported by funding from the Coastal Systems Program of the School for Marine Science and Technology, University of Massachusetts, and by the Education Department and the Reinhart Coastal Research Center of the Woods Hole Oceanographic Institution.

\section{LITERATURE CITED}

Abd Aziz SA, Nedwell DB (1986) The nitrogen cycle of an east coast, UK saltmarsh. II. Nitrogen fixation, nitrification, denitrification, tidal exchange. Estuar Coast Shelf Sci 22: 689-704

Anderson IC, Tobias CR, Neikirk BB, Wetzel RL (1997) Development of a process-based nitrogen mass balance model for a Virginia (USA) Spartina alterniflora salt marsh: implications for net DIN flux. Mar Ecol Prog Ser 159:13-27

Arenovski AL, Howes BL (1992) Lacunal allocation and gas transport capacity in the salt marsh grass Spartina alterniflora. Oecologia 90:316-322

Arth I, Frenzel P (2000) Nitrification and denitrification in the rhizosphere of rice: the detection of processes by a new multi-channel electrode. Biol Fertil Soils 31:427-435

Bodelier PLE, Duyts H, Blom CWPM, Laanbroek HJ (1998) Interactions between nitrifying and denitrifying bacteria in gnotobiotic microcosms planted with the emergent macrophyte Glyceria maxima. FEMS Microbiol Ecol 25: 63-78

Brandes JA, Devol AH (1997) Isotopic fractionation of oxygen and nitrogen in coastal marine sediments. Geochim Cosmochim Acta 61:1793-1801
Buresh RJ, DeLaune RD, Patrick WH Jr (1981) Influence of Spartina alterniflora on nitrogen loss from marsh soil. Soil Sci Soc Am J 45:660-661

Chabrerie O, Poudevigne I, Bureau F, Vinceslas-Akpa M, Nebbache S, Aubert M, Bourcier A, Alard D (2001) Biodiversity and ecosystem functions in wetlands: a case study in the estuary of the Seine River, France. Estuaries 24:1088-1096

Cline JD (1969) Spectrophotometric determination of hydrogen sulfide in natural waters. Limnol Oceanogr 14: $454-458$

Dacey JW, Howes BL (1984) Water uptake by roots controls water table movement and sediment oxidation in short Spartina marsh. Science 224:487-489

Davis JL, Nowicki B, Wigand C (2004) Denitrification in fringing salt marshes of Narragansett Bay, Rhode Island, USA. Wetlands 24:870-878

Dean JV, Biesboer DD (1985) Loss and uptake of ${ }^{15} \mathrm{~N}$-ammonium in submerged soils of a cattail marsh. Am J Bot 72: $1197-1203$

DeLaune RD, Smith CJ, Patrick WH Jr (1983) Nitrogen losses from a Louisiana Gulf Coast salt marsh. Estuar Coast Shelf Sci 17:133-141

DeLaune RD, Feijtel TC, Patrick WH Jr (1989) Nitrogen flows in Louisiana Gulf Coast salt marsh: spatial considerations. Biogeochemistry 8:25-37

Dollhopf SL, Hyun J-H, Smith AC, Adams HJ, O'Brien S, Kostka JE (2005) Quantification of ammonia-oxidizing bacteria and factors controlling nitrification in salt marsh sediments. Appl Environ Microbiol 71:240-246

Eriksson PG, Svensson JM, Carrer GM (2003) Temporal changes and spatial variation of soil oxygen consumption, nitrification and denitrification rates in a tidal salt marsh of the Lagoon of Venice, Italy. Estuar Coast Shelf Sci 58: 861-871

Haines EB, Chalmers A, Hanson R, Sherr B (1977) Nitrogen pools and fluxes on a Georgia salt marsh. In: Wiley M (ed) Estuarine processes, Vol 2. Academic Press, San Diego, CA, p 241-254

Hamersley MR, Howes BL (2003) Contribution of denitrification to carbon, nitrogen, and oxygen cycling in sediments of a New England salt marsh. Mar Ecol Prog Ser 262: $55-69$

Hefting M, Clement JC, Dowrick D, Cosandey AC and 5 others (2004) Water table elevation controls on soil nitrogen cycling in riparian wetlands along a European climatic gradient. Biogeochemistry 61:112-134

Howes BL, Goehringer DD (1994) Porewater drainage and dissolved organic carbon and nutrient losses through the intertidal creekbanks of a New England salt marsh. Mar Ecol Prog Ser 114:289-301

Howes BL, Teal JM (1994) Oxygen loss from Spartina alterniflora and its relationship to salt marsh oxygen balance. Oecologia 97:431-438

Howes BL, Dacey JWH, King GM (1984) Carbon flow through oxygen and sulfate reduction pathways in salt marsh sediments. Limnol Oceanogr 29:1037-1051

Howes BL, Dacey JWH, Teal JM (1985) Annual carbon mineralization and belowground production of Spartina alterniflora in a New England salt marsh. Ecology 66: 595-605

Howes BL, Dacey JWH, Goehringer DD (1986) Factors controlling the growth form of Spartina alterniflora: feedbacks between above-ground production, sediment oxidation, nitrogen and salinity. J Ecol 74:881-898

Howes BL, Weiskel PK, Goehringer DD, Teal JM (1996) Interception of freshwater and nitrogen transport from uplands 
to coastal waters: the role of saltmarshes. In: Nordstrom KF, Roman CT (eds) Estuarine shores: evolution, environments and human alterations. John Wiley \& Sons, New York, p 287-310

Kaplan W, Valiela I, Teal JM (1979) Denitrification in a salt marsh ecosystem. Limnol Oceanogr 24:726-734

Koch MS, Maltby E, Oliver GA, Bakker SA (1992) Factors controlling denitrification rates of tidal mudflats and fringing salt marshes in south-west England. Estuar Coast Shelf Sci 34:471-485

Lindau CW, DeLaune RD, Jones GL (1988) Fate of added nitrate and ammonium-nitrogen entering a Louisiana Gulf Coast swamp forest. J Water Pollut Control Fed 60: 386-390

Mendelssohn IA, McKee KL (1983) Root metabolic response of Spartina alterniflora in North Carolina. Ecology 60: 574-584

Norton JM, Firestone MK (1996) N dynamics in the rhizosphere of Pinus ponderosa seedlings. Soil Biol Biochem 28: 351-362

Patrick WH Jr, Reddy KR (1976) Nitrification-denitrification reactions in flooded soils and water bottoms: dependence on oxygen supply and ammonium diffusion. J Environ Qual 5:469-472

Reddy KR, Patrick WH Jr, Lindau CW (1989) Nitrification-denitrification at the plant root-sediment interface in wetlands. Limnol Oceanogr 34:1004-1013

Redfield AC (1972) Development of a New England salt marsh. Ecol Monogr 42:201-237

Risgaard-Petersen N, Jensen K (1997) Nitrification and denitrification in the rhizosphere of the aquatic macrophyte Lobelia dortmanna L. Limnol Oceanogr 42:529-537

Scheiner D (1976) Determination of ammonia and Kjeldahl N by the indophenol method. Water Res 10:31-36

Smith CJ, Patrick WH Jr (1983) Nitrous oxide emission as affected by alternate anaerobic and aerobic conditions from soil suspensions enriched with ammonium sulfate. Soil Biol Biochem 15:693-697

Smith CJ, DeLaune RD, Patrick WH Jr (1983) Nitrous oxide emission from Gulf Coast wetlands. Geochim Cosmochim Acta 47:1805-1814

Sørensen J, Rasmussen LK, Koike I (1987) Micromolar sulfide concentrations alleviate acetylene blockage of nitrous oxide reduction by denitrifying Pseudomonas flourescens. Can J Microbiol 33:1001-1005

Stepanauskas R, Davidsson ET, Leonardson L (1996) Nitrogen transformations in wetland soil cores measured by ${ }^{15} \mathrm{~N}$ isotope pairing and dilution at four infiltration rates. Appl Environ Microbiol 62:2345-2351

Sundareshwar PV, Morris JT, Keopfler EK, Fornwalt B (2003) Phosphorus limitation of coastal ecosystem processes. Science 299:563-565

Sundby B, Vale C, Caçador I, Catarino F, Madureira MJ, Caetano M (1998) Metal-rich concretion on the roots of salt marsh plants: mechanism and rate of formation. Limnol Oceanogr 43:245-252

Teal JM, Howes BL (1996) Interannual variability of a saltmarsh ecosystem. Limnol Oceanogr 41:802-809

Thompson SP, Paerl HW, Go MC (1995) Seasonal patterns of

Editorial responsibility: Victor de Jonge (Contributing Editor), Haren, The Netherlands nitrification and denitrification in a natural and a restored salt marsh. Estuaries 18:399-408

Tobias CR, Macko SA, Anderson IC, Canuel EA, Harvey JW (2001a) Tracking the fate of a high concentration groundwater nitrate plume through a fringing marsh: a combined groundwater tracer and in situ isotope enrichment study. Limnol Oceanogr 46:1977-1989

Tobias CR, Anderson IC, Canuel EA, Macko SA (2001b) Nitrogen cycling through a fringing marsh-aquifer ecotone. Mar Ecol Prog Ser 210:25-39

Trimmer M, Nedwell DB, Sivyer DB, Malcolm SJ (2000) Seasonal benthic organic matter mineralization measured by oxygen uptake and denitrification along a transect of the inner and outer River Thames estuary, UK. Mar Ecol Prog Ser 197:103-119

Valiela I, Teal JM (1979) The nitrogen budget of a salt marsh ecosystem. Nature 280:652-656

Valiela I, Teal JM, Sass WJ (1973) Nutrient retention in salt marsh plots experimentally fertilized with sewage sludge. Estuar Coast Mar Sci 1:261-269

Valiela I, Teal JM, Sass WJ (1975) Production and dynamics of salt marsh vegetation and the effects of experimental treatment with sewage sludge. J Appl Ecol 12:973-982

Valiela I, Teal JM, Persson NY (1976) Production and dynamics of experimentally enriched salt marsh vegetation: belowground biomass. Limnol Oceanogr 21:245-252

Van Raalte CD, Patriquin DG (1979) Use of the 'acetylene blockage' technique for assaying denitrification in a salt marsh. Mar Biol 52:315-320

van Wijnen HJ, Bakker JP (2000) Annual nitrogen budget of a temperate coastal barrier salt-marsh system along a productivity gradient at low and high marsh elevation. Perspect Plant Ecol Evol Syst 3:128-141

Verhagen FJM, Laanbroek HJ, Woldendorp JW (1995) Competition for ammonium between plant roots and nitrifying and heterotrophic bacteria and the effects of protozoan grazing. Plant Soil 170:241-250

Welsh DT, Bartoli M, Nizzoli D, Castaldelli G, Riou SA, Viaroli P (2000) Denitrification, nitrogen fixation, community primary productivity and inorganic-N and oxygen fluxes in an intertidal Zoster noltii meadow. Mar Ecol Prog Ser 208: $65-77$

White DS, Howes BL (1994a) Long-term ${ }^{15} \mathrm{~N}$-nitrogen retention in the vegetated sediments of a New England salt marsh. Limnol Oceanogr 39:1878-1892

White DS, Howes BL (1994b) Translocation, remineralization and turnover of nitrogen in the roots and rhizomes of Spartina alterniflora (Gramineae). Am J Bot 81:1225-1234

Wigand C, McKinney RA, Chintala MM, Charpentier MA, Groffman PM (2004) Denitrification enzyme activity of fringe salt marshes in New England (USA). J Environ Qual 33:1144-1151

Wolaver TG, Zieman JC, Wetzel R, Webb KL (1983) Tidal exchange of nitrogen and phosphorus between a mesohaline vegetated marsh and the surrounding estuary in the lower Chesapeake Bay. Estuar Coast Shelf Sci 16:321-332

Zak DR, Groffman PM, Pregitzer KS, Christensen S, Tiedje JM (1990) The vernal dam: plant-microbe competition for nitrogen in northern hardwood forests. Ecology 71:651-656

Submitted: December 9, 2004; Accepted: April 15, 2005

Proofs received from author(s): July 31, 2005 